ARGIPA. 2018. Vol. 3, No.1: 8-17

Available online: https://journal.uhamka.ac.id/index.php/argipa

p-ISSN 2502-2938; e-ISSN 2579-888X

\title{
ANALISIS KANDUNGAN ZAT GIZI MAKRO DAN DAYA CERNA PATI SNACK BAR TUJOGUNG SEBAGAI ALTERNATIF MAKANAN SELINGAN PENDERITA DIABETES TIPE 2
}

\author{
Analysis of macronutrient and starch digestibility of Tujogung snack bar as an \\ alternative food of type 2 diabetes patients
}

\section{Ika Rahmawati}

Instalasi Gizi, RSU. Multazam Medika, Tambun Selatan, Bekasi.

Email korespondensi: ikarahmawati508@gmail.com

\begin{abstract}
ABSTRAK
Diabetes melitus merupakan kumpulan gejala yang timbul pada seseorang yang mengalami peningkatan kadar glukosa darah. Kadar glukosa darah dapat dikendalikan melalui konsumsi makanan dengan tingkat indeks glikemik yang rendah serta makanan dengan daya cerna pati lambat cerna. Tujuan penelitian ini adalah untuk mengetahui pengaruh penggunaan tepung ubi jalar oranye dan jagung pada pembuatan snack bar terhadap zat gizi makro dan daya cerna pati untuk penderita diabetes tipe 2. Penelitian ini menggunakan rancangan percobaan acak lengkap (RAL) satu variabel. Penggunaan tepung ubi jalar oranye dan jagung dilakukan dengan tiga taraf (25:75, 30:70, dan 35:65). Hasil uji Kruskal-Wallis taraf penggunaan tepung ubi jalar oranye dan jagung memberikan pengaruh terhadap mutu hedonik dan tingkat kesukaan (hedonik) snack bar $(p<0,05)$. Formula terbaik adalah snack bar dengan formula 1 (25:75) dengan nilai rata-rata hedonik dan mutu hedonik tertinggi yaitu berturut-turut 3,4 dan 3,7. Hasil analisis kimia Snack bar terpilih yaitu kadar air 53,4\%, kadar abu 2,1\%, kadar protein 9,3\%, kadar lemak 8\%, dan kadar karbohidrat 27,3\%. Snack bar terpilih mengandung daya cerna pati sebesar $22,5 \%$ yang termasuk ke dalam kategori pati lambat cerna.
\end{abstract}

Kata kunci: Diabetes Tipe 2, Daya Cerna Pati, Snack Bar, Ubi Jalar Oranye, Jagung

\section{ABSTRACT}

Diabetes mellitus is a group of symptoms that arise in a person experiencing an increase in blood glucose levels. Blood glucose levels can be controlled through the consumption of foods with low glycemic index and food with slowly digestible starch. The purpose of this research was to know the influence of the use of orange sweet potato flour and corn in the processing of snack bar towards macronutrients and slowly digestible starch for diabetics type 2. This research used a randomized experimental design (CRD) one variable. This research used orange sweet potato flour and corn with three ratios (25:75, 30:70, and 35:65). Hedonic test and hedonic quality test with semi-trained panelists were used to determine the selected products. Data analysis using a nonparametric test of Kruskal-Wallis resulted that the usage of the orange sweet potato flour and corn influenced the hedonic quality and hedonic of the snack bar $(p<0,05)$. The chosen formula was a snack bar with formula 1 (25:75), which had the mean value of hedonic and hedonic quality of 3,4 and 3,7 
respectively. The results of the chemical analysis of the selected snack bar were 53,4\% moisture content, 2,1\% ash levels, 9,3\% protein, $8 \%$ fat content, and 27,3\% carbohydrates. The selected snack bars continued digestible starch of 22,5\%, this value was classified into the slowly digestible starch.

Keywords: Corn, Orange Sweet Potato, Snack Bar, Starch Digestibility, Type 2 Diabetes

\section{PENDAHULUAN}

Perubahan gaya hidup dan pola konsumsi pangan masyarakat telah berdampak terhadap peningkatan penyakit degeneratif seperti diabetes melitus. Diabetes melitus merupakan penyebab kematian nomor enam pada semua kelompok umur (Arif et al., 2013). Penderita diabetes pada usia 20-79 tahun menurut International Diabetes Federation tahun 2014 di seluruh dunia mencapai 386 juta jiwa. Indonesia berada di urutan kelima di dunia yaitu sebanyak 9,1 juta jiwa penderita diabetes. Menurut Riskesdas 2013, prevalensi diabetes melitus di Indonesia meningkat dari 1,1\% (2007) menjadi 2,4\% (2013).

Diabetes melitus adalah kumpulan gejala yang timbul pada seseorang yang mengalami peningkatan kadar glukosa darah akibat kekurangan hormon (Almatsier, 2013). Jenis diabetes yang paling banyak ditemu-kan di masyarakat ialah diabetes tipe 2. Penanganan diabetes tipe 2 difokuskan melalui olahraga dan pengaturan diet untuk mengendalikan kadar glukosa dalam darah.

Pengendalian kadar glukosa darah dapat dilakukan dengan cara nonfarmakologi yaitu melalui konsumsi makanan dengan tingkat indeks glikemik yang rendah (Larasati, 2013) serta makanan dengan daya cerna pati lambat cerna karena semakin cepat daya cerna pati pada produk pangan maka semakin cepat pula kenaikan glukosa darah (Richana et al., 2012). Penderita diabetes tipe 2 sulit mengatasi cepatnya kenaikan kadar glukosa di dalam darah.

Daya cerna pati merupakan salah satu faktor yang dapat dijadikan acuan untuk memprediksi nilai indeks glikemik pada produk pangan (Arif, et al., 2013). Definisi daya cerna pati ialah tingkat kemudahan suatu jenis pati untuk dihidrolisis oleh enzim pemecah pati menjadi unit-unit yang sederhana (Lutfika, 2006). Pati merupakan jenis karbohidrat yang terdiri atas amilosa dan amilopektin yang paling banyak dikonsumsi oleh manusia dan berperan sebagai sumber energi utama (Herawati, 2010).

Daya cerna pati yang rendah berarti hanya sedikit jumlah pati yang dapat dihidrolisis oleh enzim pencernaan dalam waktu tertentu. Dengan demikian, kadar glukosa dalam darah tidak mengalami kenaikan secara drastis setelah makanan tersebut dicerna dan dimetabolisme oleh tubuh (Arif, et al., 2013). Menurut Ragnhild, et al., (2004) 
dalam Nisviaty (2006) daya cerna pati dapat memengaruhi tinggi rendahnya indeks glikemik suatu bahan pangan.

Pada penelitian sebelumnya yang dilakukan oleh Astawan dan Widowati (2006) dalam Lutfika (2006) menunjukkan bahwa ubi jalar varietas BB00105.10 dan BB00106-18 dengan kulit berwarna merah dan daging berwarna oranye berturut-turut memiliki daya cerna pati yang rendah yaitu sebesar 51,4\%-44,6\% dan kadar amilosa sebesar 24,94\%-26,08\%. Ubi jalar memiliki indeks glikemik sebesar 54 dan tergolong dalam kategori rendah (Widyaningtyas, et al., 2015).

Jagung mengandung serat pangan yang dibutuhkan tubuh dengan indeks glikemik relatif rendah dibanding padi sehingga jagung menjadi bahan anjuran bagi penderita diabetes (Suarni dan Yasin, 2011). Menurut penelitian, daya cerna pati dari delapan jenis jagung berkisar antara 59,73\%-66,68\%, kemudian serat tidak larut air dan serat larut air berturut-turut yang terkandung pada delapan jenis jagung sebesar 5,02\%$6,60 \%$ dan $1,1 \%-1,3 \%$, dan indeks glikemiknya sebesar 28,66-41,74. Nilai tersebut sangat cocok diaplikasikan pada diet bagi penderita diabetes (Richana, et al., 2012).

Di Indonesia, snack bar sering dikaitkan dengan makanan rendah kalori. Snack bar bagi penderita penyakit kronis telah banyak dikembangkan, salah satunya bagi penderita diabetes.
Makanan selingan bagi penderita diabetes tipe 2 dianjurkan sebesar $10-15 \%$ dari kebutuhan dan dapat dikonsumsi 2-3 kali sehari. Snack bar telah dikembangkan bagi penderita diabetes untuk makanan selingan yang dapat membantu mencegah hiperglikemia dengan bahan baku rendah indeks glikemik dan pati lambat cerna.

\section{METODE}

Bahan baku utama yang digunakan dalam penelitian ini ialah ubi jalar oranye dan jagung. Ubi jalar oranye dan jagung merupakan bahan makanan yang memiliki indeks glikemik rendah. Pada tahap awal dilakukan pembuatan tepung ubi jalar oranye. Tahapan pembuatan tepung ubi jalar oranye sesuai dengan yang dilakukan oleh Nisviaty (2006). Diawali dengan memilih ubi jalar yang bebas dari hama penyakit (tidak berulat), dibersihkan tanahnya dengan air mengalir kemudian dikupas kulitnya, dan direndam air untuk menghindari kontak langsung dengan udara yang dapat mengakibatkan ubi jalar menjadi coklat. Kemudian, ubi kembali direndam dengan larutan sodium-bisulfit $0,3 \%$ selama \pm satu jam setelah proses penyawutan. Hal ini bertujuan untuk menghilangkan kotoran dan getah yang masih menempel pada ubi jalar sawut serta menghindari terjadinya proses pencoklatan (browning).

Untuk menghilangkan air hasil perendaman dilakukan pencucian dan penirisan dengan mesin peniris. 
Setelah itu, ubi jalar sawut dikeringkan dengan menggunakan oven pada suhu $50{ }^{\circ} \mathrm{C}$ selama \pm 8 jam. Pemilihan suhu dilakukan untuk meminimalisasi perubahan warna dari tepung yang dihasilkan. Selanjutnya, ubi jalar sawut kering digiling dengan disc mill kemudian diayak dengan ayakan 80 mesh hingga didapat tepung ubi jalar yang halus.

Setelah itu, dilakukan pembuatan puree jagung. Jagung yang akan digunakan dikukus terlebih dahulu kemudian dihaluskan menggunakan blender. Pengukusan dilakukan dengan tujuan mempertahankan warna dan menghilangkan rasa langu yang khas pada jagung. Setelah dihaluskan, jagung disaring agar terpisah dari ampasnya.

Formulasi substitusi tepung ubi jalar oranye terhadap puree jagung dilakukan dengan tiga taraf yaitu F1 (25:75), F2 (30:70), dan F3 (35:65). Cara pembuatan snack bar yaitu dengan mencampurkan telur ayam dan gula kemudian diaduk sampai rata dengan mixer kecepatan rendah, lalu susu skim bubuk, vanilli, dan tepung ubi jalar oranye. Setelah tercampur rata, mentega dan pasta jagung dicampurkan pada adonan kemudian aduk kembali dengan mixer kecepatan rendah. Adonan kemudian dimasukkan ke dalam oven yang sudah dipanaskan sebelumnya dengan suhu oven \pm 150 o $\mathrm{C}$ dan waktu pemanggangan \pm 60 menit.

Penelitian ini dilaksanakan selama enam bulan, dari bulan Mei sampai Oktober 2017. Pembuatan tepung ubi jalar oranye dilakukan di Laboratorium Balai Penelitian dan Pengembangan Pasca Panen, Bogor. Analisis proksimat dilakukan di Laboratorium Balai Besar Industri Agro, Bogor. Analisis daya cerna pati dilakukan di Laboratorium Kimia PAU, Institut Pertanian Bogor. Uji organoleptik dilakukan di Laboratorium Gizi, Fakultas Ilmu-ilmu Kesehatan, Universitas Muhammadiyah Prof. DR. Hamka.

Panelis yang digunakan merupakan panelis semi terlatih dengan jumlah 32 orang dengan karakteristik panelis sehat dan menyukai snack bar. Data yang diperoleh dianalisis statistik dengan uji nonparametrik Kruskal-Wallis dan dilanjutkan dengan uji lanjut nonparametrik MannWhitney dengan tingkat signifikansi $95 \%$.

\section{HASIL}

Uji mutu hedonik bersifat spesifik, digunakan untuk mengetahui karak-teristik snack bar terhadap mutu aroma, rasa, dan tekstur snack bar. Uji hedonik (tingkat kesukaan) dilakukan untuk mengetahui penerimaan produk. Parameter yang diukur dalam uji hedonik meliputi aroma, rasa, dan tekstur.

\section{Aroma}

Aroma pada snack bar Tujogung dipengaruhi oleh taraf penggunaan puree jagung, margarin, telur, dan vanili. Berdasarkan hasil uji nonparametrik Kruskal-Wallis taraf peng- 
gunaan tepung ubi jalar oranye dan puree jagung berpengaruh terhadap mutu aroma snack bar pada Formula 1, Formula 2, dan Formula $3(p<0,05)$. Uji lanjut non-parametrik Mann-Whitney menunjukkan bahwa tidak ada perbedaan yang signifikan antara Formula 1 dengan Formula $2(p>0,05)$. Namun, keduanya secara signifikan berbeda $(p<0,05)$ dengan Formula 3.

Uji nonparametrik KruskalWallis menunjukkan adanya pengaruh $(p<0,05)$ kesukaan panelis terhadap aroma snack bar pada masing-masing formulasi. Uji lanjut nonparametrik Mann-Whitney menunjukkan bahwa kesukaan panelis terhadap aroma snack bar konsisten dengan penilaian terhadap mutu aroma snack bar. Formula 1 dengan Formula 2 tidak ada perbedaan kesukaan yang signifikan. Sedangkan, kesukaan terhadap aroma snack bar Formula 1 dengan Formula 3 menunjukkan ada perbedaan yang signifikan, begitu pula kesukaan terhadap aroma snack bar pada Formula 2 dengan Formula 3. Tingkat kesukaan panelis terhadap Formula 3 secara signifikan lebih rendah dibandingkan kesukaan panelis terhadap dua formula lainnya.

\section{Rasa}

Rasa berbeda dengan aroma dan lebih banyak melibatkan indera pengecapan. Kuncup rasa pada lidah memiliki beberapa tipe reseptor rasa, setiap tipe akan mendeteksi satu jenis rasa dari 5 rasa dasar yaitu asam, asin, manis, pahit, dan umami (Jacewicz, 2008).
Hasil uji nonparametrik KruskalWallis menunjukkan taraf penggunaan tepung ubi jalar oranye dan puree jagung berpengaruh terhadap rasa snack bar pada Formula 1, Formula 2, dan Formula $3(p<0,05)$. Uji lanjut nonparametrik Mann-Whitney menunjukkan bahwa tidak ada perbedaan yang signifikan antara Formula 1 dengan Formula $2(p>0,05)$. Pada Formula 1 dengan Formula 3 ada perbedaan yang signifikan $(p<0,05)$ sedangkan, pada Formula 2 dengan Formula 3 juga terdapat perbedaan yang signifikan $(p<0,05)$.

Uji nonparametrik Kruskal-
Wallis
menunjukkan adanya perbedaan kesukaan panelis terhadap rasa snack bar pada masing-masing formulasi $(p<0,05)$. Uji lanjut nonparametrik Mann-Whitney menunjukkan bahwa kesukaan panelis terhadap rasa snack bar Formula 1 dengan Formula 2 tidak berbeda nyata $(p>0,05)$. Sedangkan, kesukaan panelis terhadap rasa snack bar Formula 1 dan Formula 2 berbeda secara signifikan $(p<0,05)$ dengan Formula 3. Semakin berkurang taraf penggunaan puree jagung, maka snack bar semakin tidak disukai oleh panelis. Karena, konsentrasi puree jagung pada masingmasing Formula memengaruhi mutu rasa.

\section{Tekstur}

Tekstur atau viskositas bahan pangan dapat mengubah rasa dan aroma yang timbul (Winarno, 2008). Penilaian tekstur pada snack bar Tujogung berfokus pada keempukan 
snack bar, karena taraf penggunaan tepung ubi jalar dan puree jagung akan memengaruhi keempukan snack bar.

Uji non-parametrik KruskalWallis menunjukkan taraf penggunaan tepung ubi jalar oranye dan puree jagung menyebabkan perbedaan nyata terhadap tekstur snack bar pada Formula 1, Formula 2, dan Formula 3 $(p<0,05)$. Uji lanjut non-parametrik Mann-Whitney yang menunjukkan bahwa tidak ada perbedaan yang signifikan antara Formula 1 dengan Formula $2(p>0,05)$. Pada Formula 1 dengan Formula 3 ada perbedaan yang signifikan $(p<0,05)$ sedangkan, pada Formula 2 dengan Formula 3 juga terdapat perbedaan yang signifikan $(p<0,05)$.

Uji nonparametrik KruskalWallis menunjukkan adanya perbedaan $(p<0,05)$ kesukaan panelis terhadap tekstur snack bar pada masing-masing formula. Uji lanjut nonparametrik Mann-Whitney menunjukkan bahwa kesukaan terhadap mutu tekstur snack bar Formula 1 dengan Formula 2 tidak memiliki perbedaan yang signifikan. Sementara itu, kesukaan terhadap tekstur snack bar Formula 1 dengan Formula 3 terdapat perbedaan yang signifikan, begitu pula tekstur snack bar pada Formula 2 dengan Formula 3. Semakin tinggi taraf penggunaan puree jagung, tekstur snack bar semakin disukai oleh panelis.

\section{Penentuan Produk Terbaik}

Dari hasil analisis statistik, didapatkan produk yang memiliki nilai tertinggi berdasarkan hasil uji hedonik. Untuk mendapatkan kesimpulan mengenai produk yang unggul berdasarkan penilaian aroma, rasa, dan tekstur, maka dilakukan Metode Perbandingan Eksponensial (MPE).

Formula terbaik ditentukan dengan cara pembobotan berdasarkan hasil uji tingkat kesukaan (hedonik) menggunakan sebagian Metode Perbandingan Eksponensial (MPE; Setyaningsih, et al., 2010). Penentuan produk terbaik dengan cara pembobotan tidak didasarkan pada hasil analisis fisikokimia sebab adanya keterbatasan dalam penelitian.

Tabel 1.

Rerata dan total skor penilaian uji hedonik

\begin{tabular}{lcrrrrr}
\hline Aspek & \multicolumn{2}{c}{ F1 } & \multicolumn{2}{c}{ F2 } & \multicolumn{2}{c}{ F3 } \\
\cline { 2 - 7 } Penilaian & Rerata & Skor & Rerata & Skor & Rerata & Skor \\
\hline Aroma & 3,8 & 11,4 & 3,7 & 11,1 & 3,0 & 9,0 \\
Rasa & 2,9 & 5,8 & 3,2 & 6,4 & 2,2 & 4,4 \\
Tekstur & 3,5 & 3,5 & 3,1 & 3,1 & 2,5 & 2,5 \\
\hline Total & \multicolumn{5}{c}{20,7} \\
\hline Keterangan: \\
F1: perbandingan tepung ubi jalar dengan jagung (25:75), \\
F2: (30:70), dan F3: (35:65)
\end{tabular}


Urutan peringkat ditentukan berdasarkan karakteristik produk yaitu aspek penilaian produk yang paling menunjukkan adanya perbedaan yang signifikan antara kelompok perlakuan. Semakin tinggi urutan peringkat aspek penilaian maka menunjukkan bahwa pada aspek penilaian tersebut terdapat perbedaan yang signifikan antara kelompok perlakuan. Aroma diberikan bobot 3, kemudian rasa dan tekstur masing-masing secara berurutan diberi bobot 2 dan 1 .

Formula 3 secara statistik lebih tidak disukai oleh panelis, sehingga pilihan yang tersisa adalah Formula 1 dan Formula 2. Di antara dua formula tersebut, Formula 1 memiliki rata-rata lebih tinggi pada dua aspek mutu snack bar, yaitu aroma dan tekstur. Oleh karena itu, formula terpilih adalah Formula 1 dengan perbandingan 25:75 tepung ubi jalar oranye dan jagung dengan nilai skor penilaian uji hedonik sebesar 20,7.

\section{Deskripsi Produk Snack Bar Terbaik}

Snack bar terpilih setelah uji mutu hedonik dan hedonik (kesukaan) kemudian dianalisis kandungan gizinya, terdiri dari kadar air, protein, lemak, karbohidrat, dan daya cerna pati. Snack bar terpilih yang dianalisis yaitu snack bar F1 dengan taraf perbandingan tepung ubi jalar dengan jagung 25:75.

Nilai kandungan gizi snack bar menjadi komponen yang penting dalam produk snack bar terpilih. Nilai kandungan gizi pada snack bar terpilih ditampilkan pada Tabel 2. Kadar air snack bar Tujogung adalah 53,4\%. Nilai ini lebih besar dari kadar air pada produk olahan panggang berupa cake tepung ubi jalar oranye yang hanya memiliki kadar air sebesar 24,73\% (Lutfika, 2006). Tingginya kadar air pada snack bar Tujogung disebabkan oleh bahan baku yang digunakan serta ketebalan produk pada saat proses pemanggangan. Snack bar Tujogung menggunakan puree jagung yang mengandung air sehingga meningkatkan kadar air produk.

Kadar abu produk terpilih snack bar sebesar 2,1\%. Kadar abu pada snack bar terpilih lebih tinggi dibandingkan dengan kadar abu pada cake tepung ubi jalar oranye yaitu 1,49\% (Lutfika, 2006). Abu yang terdapat pada snack bar sebagian besar berasal dari tepung ubi jalar oranye.

Tabel 2.

Hasil analisis kimia snack bar tujogung terpilih

\begin{tabular}{lcc}
\hline Parameter & Satuan & $\begin{array}{c}\text { Hasil } \\
\text { Analisis }\end{array}$ \\
\hline Air & $\%$ & 53,4 \\
Abu & $\%$ & 2,1 \\
Protein & $\%$ & 9,3 \\
Lemak & $\%$ & 8,0 \\
Karbohidrat & $\%$ & 27,3 \\
Daya Cerna Pati & $\%$ & 22,5 \\
\hline
\end{tabular}


Kadar protein snack bar sebesar 9,3\%. Kadar protein snack bar Tujogung lebih tinggi jika dibandingkan dengan cake berbahan dasar tepung ubi jalar oranye yaitu sebesar 6,05\% (Lutfika, 2006). Tingginya kadar protein snack bar Tujogung berasal dari bahan sumber protein yang digunakan dalam pembuatan snack bar yaitu jagung, telur, dan susu.

Kadar lemak snack bar Tujogung yaitu sebesar $8 \%$. Kadar lemak pada snack bar Tujogung lebih rendah bila dibandingkan dengan cake berbahan dasar tepung ubi jalar oranye yang dibuat oleh Lutfika (2006) yaitu sebesar $20,31 \%$.

Kadar karbohidrat (by difference) produk terpilih yaitu sebesar $27,3 \%$. Nilai tersebut berada di bawah nilai cake tepung ubi jalar oranye yaitu sebesar 47,42\% (Lutfika, 2006) dan hanya sepertiga kandungan karbohidrat cookies berbahan dasar sama (Claudia, et al., 2015). Perbedaan pemanggangan terhadap karbohidrat umumnya terkait dengan terjadinya hidrolisis. Peranan karbohidrat sederhana dan kompleks dalam reaksi Maillard dapat menurunkan ketersediaan karbohidrat pada produkproduk hasil pemanggangan (Palupi, et al., 2007).

Daya cerna pati snack bar Tujogung sebesar $22,5 \%$. Nilai tersebut termasuk ke dalam kategori rendah atau pati lambat cerna. Pada penelitian yang dilakukan Lutfika
(2006) kadar daya cerna pati pada cake tepung ubi jalar oranye yaitu sebesar $26,56 \%$.

\section{DISKUSI}

Snack bar yang dihasilkan melalui penelitian ini diharapkan dapat dijadikan makanan selingan bagi penderita diabetes mellitus. Daya cerna pati merupakan parameter yang digunakan untuk menunjukkan kemampuan pencernaan dan penyerapan pati oleh tubuh. Ketika pati dicerna, setiap jenis pati akan memproduksi kelompok monosakarida, yaitu glukosa kemudian akan diserap dalam darah. Oleh karena itu, tubuh akan merangsang pankreas untuk memproduksi insulin.

Semakin tinggi tingkat daya cerna pati semakin cepat dan semakin banyak glukosa yang dihasilkan, maka insulin yang dibutuhkan untuk mengubah glukosa menjadi energi juga semakin banyak (Richana, et al., 2012). Daya cerna pati yang rendah berarti hanya sedikit pati yang terhidrolisis oleh enzim pencernaan dalam kurun waktu tertentu. Dengan demikian, kadar glukosa dalam darah tidak mengalami kenaikan secara drastis sesaat setelah makanan dicerna dan dimetabolisme oleh tubuh (Arif, 2013).

Daya cerna pati merupakan faktor yang memengaruhi indeks glikemik suatu pangan (ArvidssonLenner, et al., 2004). Indeks glikemik merupakan tingkatan pangan menurut efeknya terhadap glukosa darah. 
Pangan yang memiliki indeks glikemik tinggi dapat menaikkan kadar glukosa darah dengan cepat (Atkinson, et al., 2008).

Makanan selingan bagi

penderita diabetes tipe 2 dianjurkan sebesar $10-15 \%$ dalam satu kali makanan selingan dari kebutuhan kalori untuk penderita diabetes yaitu 1900 kkal. Berdasarkan hasil perhitungan, snack bar terpilih dengan satu takaran saji 43,5 gram memiliki kandungan energi $95 \mathrm{kkal}$, lemak total 4 gram, protein 4 gram, dan karbohidrat total 12 gram. Jika snack bar dikonsumsi sebanyak dua kali, maka kebutuhan energi dalam satu kali makanan selingan dapat terpenuhi.

\section{DAFTAR RUJUKAN}

Almatsier, S. (2013). Penuntun Diet: Instalasi Gizi Perjan RS Dr. Cipto Mangunkusumo dan Asosiasi Dietisien Indonesia. Jakarta: PT Gramedia Pustaka Utama.

Arif, AB., Budiyanto, A., \& Hoerudin. (2013). Nilai indeks glikemik produk pangan dan faktor-faktor yang memengaruhinya. J Litbang Pert, 32(3):91-99.

Arvidsson-Lenner, R., Asp, NG., Axelsen, M., Bryngelsson, S., Haapa, E., Jarvi, A., et al. (2004). Glycaemix index. Scandinavian Journal of Nutrition, 48(2):84-94.

Atkinson, FS., Foster-Powell, K., \& Brand Miller, JC. (2008). International tables of glycemic index and glycemic load values: 2008. Diabetes Care, 31:2281-2283.
[Balitbangkes] Badan Penelitian dan Pengembangan Kesehatan. (2013, December 1). Riset Kesehatan Dasar (RISKESDAS) 2013. January $\quad 13, \quad 2017$. www.depkes.go.id/resources/do wnload/general/Hasil\%20Riskes das $\% 202013$.pdf

Claudia, R., Estiasih, T., Ningtyas, DW., \& Widyastuti, E. (2015). Pengembangan biskuit dari tepung ubi jalar oranye (ipomoea batatas l.) dan tepung jagung (zea mays) fermentasi: Kajian pustaka. Jurnal Pangan dan Agroindustri, 3(4):1589-1595.

Herawati, H. (2010). Potensi pengembangan produk pati tahan cerna sebagai pangan fungsional. Jurnal Litbang Pertanian, 30(1):31-39.

International Diabetes Federation. (2014). Diabetes Atlas Sixth Edition. [cited 2017, January 07]. Available from: www.idf.org/diabetesatlas

Jacewicz, M. (2008, July 20). Smell and taste disorders (Merck Manual Hand Books). January 07, 2017. http://www.merckmanuals.com /home/print/ear_nose_and_thro atdisorders/nose_sinus_and_tast e_disorders/smell_and_taste_dis orders.html\#index.

Larasati, AS. (2013). Analisis Kandungan Zat Gizi Makro dan Indeks Glikemik Snack Bar Beras Warna sebagai Makanan Selingan Penderita Nefropati Diabetik. Skripsi. Semarang: Fakultas Kedokteran Universitas Diponegoro. 
Lutfika, E. (2006). Evaluasi Mutu Gizi dan Indeks Glikemik Produk Olahan Panggang Berbahan Dasar Tepung Ubi Jalar (Ipomoea batatas L.) Klon Unggul Bb00105.10. Skripsi. Bogor: Institut Pertanian Bogor.

Nisviaty, A. (2006). Pemanfaatan Tepung Ubi Jalar (Ipomoea Batatas L.) Klon Bb00105.10 Sebagai Bahan Dasar Produk Olahan Kukus serta Evaluasi Mutu Gizi dan Indeks Glikemiknya. Skripsi. Bogor: Institut Pertanian Bogor.

Palupi, NS., Zakaria, FR., \& Prangdimurti, E. (2007). Perbedaan Pengolahan terhadap Nilai Gizi Pangan. Departemen Ilmu dan Teknologi Pangan, Institut Pertanian Bogor. http://www.academia.edu/2375 7816/Perbedaan_Pengolahan_ter hadap_Nilai_Gizi_Pangan.

Richana, N., Ratnaningsih, Arif, AB. \& Hayuningtyas, M. (2012).
Characterization of Eight Maize Varieties with a Low Glycemic Index to Support Food Security. Indonesian Center for Agricultural Postharvest Research and Development, Proceeding. 178-183.

Setyaningsih, D., Apriyantono, A. \& Sari, MP. (2010). Analisis Sensori untuk Industri Pangan dan Agro. Bogor: IPB Press.

Suarni \& Yasin, M. (2011). Jagung sebagai sumber pangan fungsional. Iptek Tanaman Pangan, 6(1):41-56.

Widyaningtyas, M. \& Susanto, WH. (2015). Perbedaan jenis dan konsentrasi hidrokoloid (carboxy methyl cellulose, xanthan gum, dan karagenan) terhadap karakteristik mie kering berbasis pasta ubi jalar varietas Ase Kuning. Jurnal Pangan dan Agroindustri, 3(2):417-423.

Winarno, FG. (2008). Kimia Pangan dan Gizi. Jakarta: PT. Gramedia Pustaka Utama. 